\title{
The architecture of Phaseolus vulgaris root is altered when a defense response is elicited by an oligogalacturonide
}

\author{
Georgina Hernández Mata, Baldemar Sepúlveda, Alan Richards and Eva Soriano*
}

Instituto de Investigaciones Químico-biológicas. Universidad Michoacana de San Nicolás de Hidalgo, Morelia 58030, México; * Corresponding author:esoriano@zeus.umich.mx

Received: 05/10/2005, Accepted: 20/01/2006

Phytoalexin accumulation is one of a myriad of plant defense responses; these responses can be elicited by pathogens or molecules such as oligogalacturonides (OGAs). Phytoalexin production has been considered a vital component of the resistance mechanisms that determine the outcome of many plant-microbe interactions. Besides inducing defense responses, OGAs have been shown to affect plant development, which normally is controlled by plant hormones, particularly auxin. In this work we measured phytoalexin accumulation in roots of bean (Phaseolus vulgaris L.) seedlings grown in the presence or absence of the auxin 3-naphtalenacetic acid (NAA) and treated with a decagalacturonide $\left(\mathrm{OGA}_{10}\right)$. We found that $\mathrm{OGA}_{10}(0.01 \mathrm{mM})$ caused phytoalexin production and also inhibited main root elongation and the formation of secondary roots by ca. 33\%. Expression of $C y c b$ 2-2 was also inhibited, while pal and chs were highly expressed. The root growth inhibition was not overcome by the addition of a stimulatory concentration of auxin (NAA $0.1 \mu \mathrm{M}$ ). The data suggests that elicitation of defense responses in the root alters metabolism in such a way that results in the modification of the architecture of bean roots.

Key words: Auxin, phytoalexin, Phaseolus vulgaris, root.

\begin{abstract}
A arquitetura das raízes de Phaseolus vulgaris é alterada quando respostas de defesa é induzida por um oligogalacturonídeo: O acúmulo de fitoalexinas forma parte das múltiplas respostas de defesa das plantas e estas respostas podem ser induzidas por patógenos ou por moléculas tais como os oligogalacturonideos (OGAs). O resultado de uma interação plantamicroorganismo é em parte determinado pela produção de fitoalexinas. Tem sido encontrado que além de induzir as defesas, os OGAs afetam o desenvolvimento das plantas, o qual normalmente é regulado pelos hormônios vegetais, em particular pela auxina. Neste trabalho medimos o acúmulo de fitoalexinas em raízes em desenvolvimento de plântulas de Phaseolus vulgaris L. (feijão comum) tratadas com um decagalacturonídeo $\left(\mathrm{OGA}_{10}\right)$ em presença e ausência da auxina ácido 3-naftalenacético (ANA). Observou-se que quando se induz a produção de fitoalexinas com $\mathrm{OGA}_{10}(0.01 \mathrm{mM})$ se inibe a elongação da raiz principal e a formação das raízes laterais em aproximadamente 33 \%. A expressão de $C y c b$ 2-2 foi também inibida, quando os genes de pal e chs estão expressando-se. A adição de auxina $(0.1 \mu \mathrm{M})$ não eliminou a inibição do desenvolvimento da raiz, ainda que tal concentração de ANA é estimulatória do crescimento da raiz. Estes dados sugerem que a indução de defesas na raiz traz como consequência mudanças no metabolismo da planta, que levam a deter os eventos do crescimento enquanto se responde a um ataque de enfermidade simulado por $\mathrm{OGA}_{10}$.

Palavras-chave: Phaseolus vulgaris L., auxina, fitoalexinas, raíz.
\end{abstract}

Molecules generally known as elicitors, regardless of their chemical nature, are capable of inducing defense responses in plants. The role of oligogalacturonide acid (14 linked $\alpha$-D-oligo-GalUA:OGA) as an elicitor has been extensively studied (Ridley et al., 2001); these molecules are believed to be produced during the plant-microorganism interaction and are capable of inducing the formation of antimicrobial compounds or phytoalexins in plant tissues (Spiro et al., 1993). It is well known that interaction with fungal polygalacturonase favors the release of elicitor- 
active oligogalacturonides from plant cell walls (Shevell et al., 2000; De Lorenzo et al., 2001). On the other hand, it has been reported that oligogalacturonides could interfere with root development of cucumber seedlings (Spiro et al., 2002) or root formation in tobacco explants; however, root inhibition in tobacco explants was eliminated by addition of auxin (Bellicampi et al., 1993). Recently, it has been found that galacturonides are critical in plant growth, perhaps by modifying cell wall structure (Capodicasa et al., 2004). In this work we report the results of treating bean seedlings with a decagalacturonide purified from bean cell wall, which is an effective elicitor of defenses in bean vegetative tissues (Cano et al., 1994). The effect of the oligogalacturonide $\left(\mathrm{OGA}_{10}\right)$ on phytoalexin production, root architecture and gene expression was measured in elongating roots of Phaseolus vulgaris seedlings. These effects were not corrected by the addition of the auxin 3-naphtalenacetic acid (NAA). Apparently, when defense metabolism was activated, $C y c$ b 2-2 expression decreased and root development was inhibited.

Seeds of $P$. vulgaris L. cv Flor de mayo M-38 (obtained from INIFAP Campo Experimental, Celaya, México) were germinated in asceptic conditions and seedlings with tap roots of 1-2 $\mathrm{cm}$ length were placed in tubes (one bean seedling each per tube) containing $10 \mathrm{ml}$ Hoagland's nutrient solution; care was taken to ensure that the seedlings were not submerged in the solution but that only the roots were bathed by it. The tubes were incubated in a growth chamber under controlled environmental conditions $\left(26-28^{\circ} \mathrm{C}\right.$ temperature, $12 / 12 \mathrm{~h}$ photoperiod at $350 \mu \mathrm{mol} \cdot \mathrm{m}^{-2} \cdot \mathrm{s}^{-1}$ irradiance). The nutrient solution contained either $\mathrm{OGA}_{10}(1,4$-linked $\alpha$-Doligogalacturonide; PD =10), NAA (3-naphtalen acetic acid) (Sigma Chemical Co., St. Louis, MO.) or both compounds, at different concentrations depending on the experiment. The elicitor $\mathrm{OGA}_{10}$ was prepared according to Dixon et al. (1989), except that bean cell walls were the source of polypectate instead of citrus polypectate; bean cell walls were digested until a fraction with polymerization degree $=10\left(\mathrm{OGA}_{10}\right)$ was obtained (Soriano and García, 1993). Phytoalexin production in the roots was determined by measuring phaseollin, an isoflavonoid phytoalexin, using a thin-layer chromatography technique according to the method reported in Theodorou et al. (1982). Samples of ten plants were used for each phaseollin determination and were derived from material obtained from the same batch of seedlings. Data are the average of three determinations $\pm \mathrm{sd}$. $\mathrm{P}>0.05$.

RNA extraction and RNA Gel Blot Analysis were performed at different time intervals after oligogalacturonide treatment according to Pawlowski et al. (1994). Nucleic acids were precipitated from the supernatant after centrifugation at $8,000 \mathrm{rpm}\left(4^{\circ} \mathrm{C} ; 10 \mathrm{~min}\right)$ with $3 \mathrm{M}$ sodium acetate $(50 \mu \mathrm{L})$ and ethanol $(1,000 \mu \mathrm{L})$ incubated at $-20^{\circ} \mathrm{C}$. RNA quality was determined by gel fractionation before analyzing for specific mRNAs (Maniatis et al., 1982): pal phenylalanine ammonialyase; chs chalcone synthase; Cycb2-2 Cycline B2-2. RNA quantity was determined by absorbance at two wavelengths, 260 and $280 \mathrm{~nm}$, and purity calculated by the quotient Abs269/Abs280. For RNA-blot analysis, total root RNA was fractionated by electrophoresis on $1.45 \%$ agarose gels with formaldehyde and blotted onto nylon membranes (Hybond$\mathrm{N}+$, Amersham Pharmacia Biotech). Labeled probes were generated with a quimiluminescence kit (Neblot Phototope kit, New England BioLabs) by using cDNAs encoding bean phenylalanine ammonia-lyase, chalcone isomerase and cycline $2 \mathrm{~b}-2$. An $18 \mathrm{~S}$ rRNA gene probe was used as a loading control. Membranes were exposed to X-Omat Film (Kodak) after being treated with detection kit (Phototop-Star Detection kit for nucleic acids, New England Biolabs). Band intensity was determined using the Program Kodak Digital Science 1D and plotted as band intensities or relative to control values. The experiment was performed twice with similar results.

Root system measurements were carried out with a stereomicroscope for both the primary and the secondary roots after $\mathrm{OGA}_{10}$ or/and NAA treatment. Primary root length was determined for each root using a plastic ruler. For lateral root number data, the primary root was observed with the 3x objective (Nikkon Microscope) and all emerging lateral

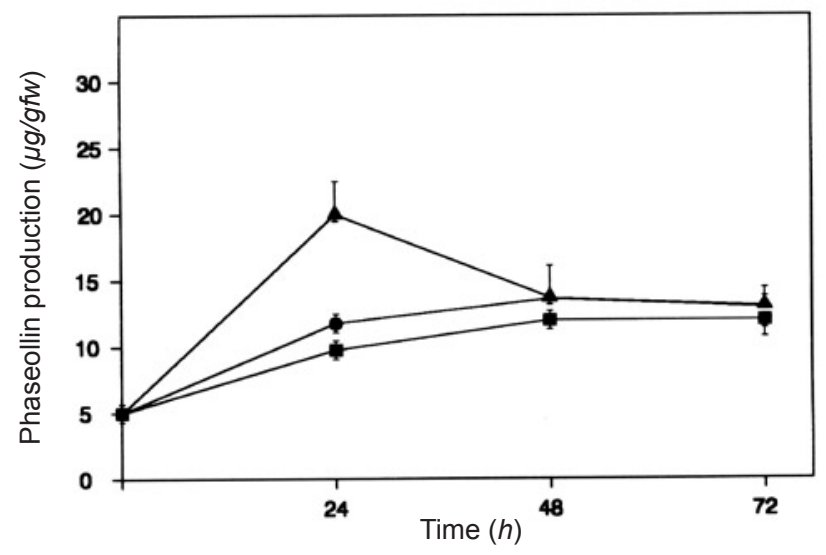

Figure 1. Time-course production of phaseollin elicited by oligogalacturonides. Phaseollin was extracted from the roots of bean seedlings incubated in MS medium with $10 \mu \mathrm{M} \mathrm{OGA}_{10}$ $(\bullet)$ or 10 nM NAA $(\boldsymbol{\square})$. Control plants $(\boldsymbol{\Delta})$ were incubated without any addition. 

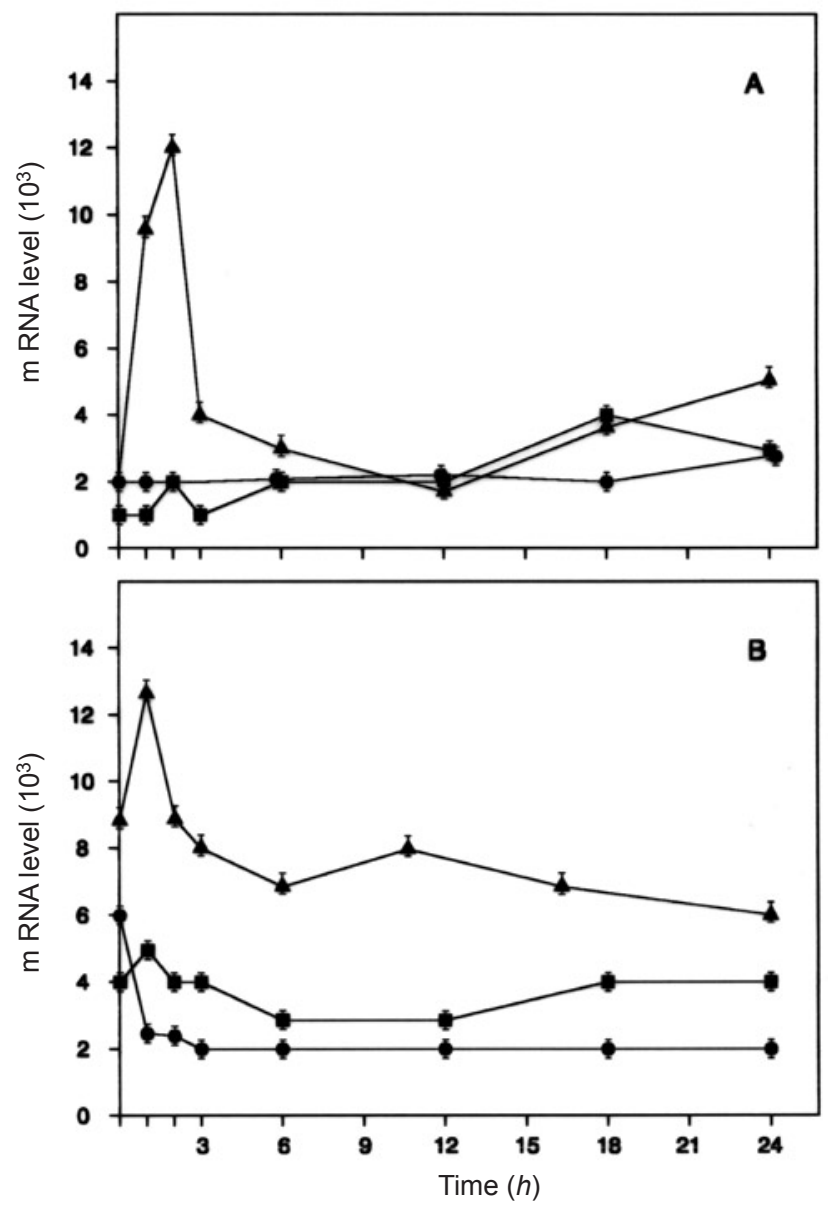

Figure 2. Accumulation of mRNA of pal (A) and chs (B) in roots. Bean seedlings were grown over a $24 \mathrm{~h}$ period after treatment with $\mathrm{OGA}_{10}(\bullet)$ or NAA $(\boldsymbol{\Delta})$; control $(\bullet)$. mRNA was determined in the roots of $P$. vulgaris seedlings by Densitometric Analysis of Northern Blot bands.

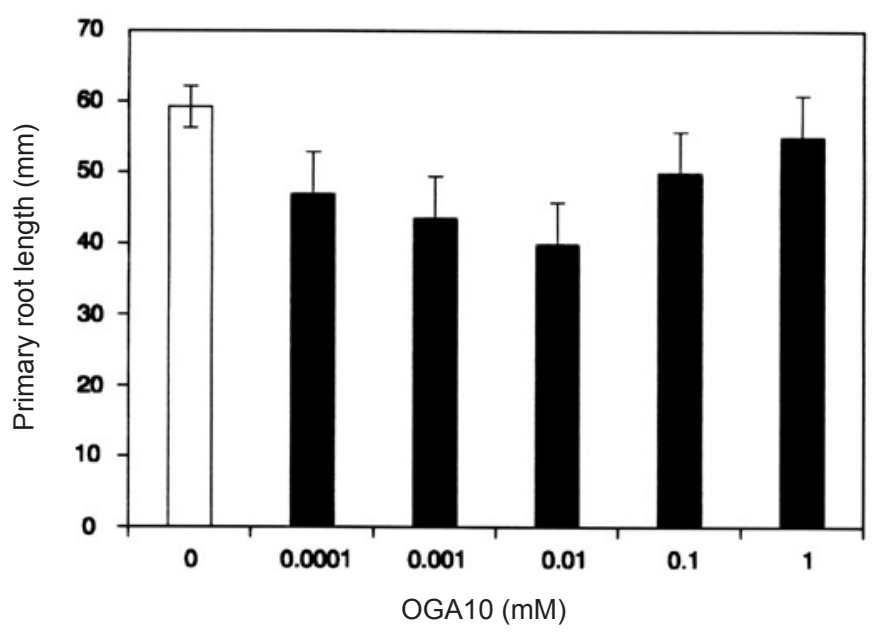

Figure 3. Dose response of primary root to $\mathrm{OGA}_{10}$. Root length was measured in germinated bean seeds after growing in nutrient solution for 3 days in presence of $\mathrm{OGA}_{10}$ at the indicated concentration. roots were counted. Samples were composed of ten plants each and the experiment was repeated in three independent experiments. Data are the average of three determinations \pm std, $\mathrm{P}<0.05$.

In order to test the ability of bean roots to accumulate the phytoalexin phaseollin in response to $\mathrm{OGA}_{10}$, a time-course experiment was performed. A transient peak of phaseollin production was observed, after treatment with $0.01 \mathrm{mM}$ OGA $_{10}$ (figure 1). This response was similar to that observed in other bean tissues (Cano et al., 1994) where a marked accumulation of phaseollin occurred at $24 \mathrm{~h}$. The mRNAs corresponding to the defense-related genes were expressed at an early time after $\mathrm{OGA}_{10}$ treatment; figure $2 \mathrm{~A}$ shows the increase of pal mRNA levels above those of control plants at $0.5 \mathrm{~h}$ after $\mathrm{OGA}_{10}$ addition; it is known that there are at least three pal genes in bean which are differentially regulated by development and by defense (Cramer et al., 1985; Maher et al., 1994) and only pal mRNA responsive to the defense elicitor is shown (figure 2A). Similarly, chs mRNA increased above control levels at $0.5 \mathrm{~h}$ after treatment and remained high for the first $24 \mathrm{~h}$ as shown in figure $2 \mathrm{~B}$. This indicates that synthesis de novo of phytoalexins in the roots occurred with $\mathrm{OGA}_{10}$ elicitation as already reported for other elicited tissues (Richard et al., 2000). In both cases, auxin treatment caused no elevation of both mRNAs (figure 2A and B) during those early hours, which correlates with the absence of phytoalexin production when the root tissue was treated with $0.01 \mu \mathrm{M}$ NAA, as shown in figure 1 .

The effect of $\mathrm{OGA}_{10}$ on bean root architecture was tested by placing bean plants in the presence of different concentrations of elicitor $\left(0.1 \mu \mathrm{M}\right.$ to $\left.1 \mathrm{mM} \mathrm{OGA}_{10}\right)$ during three days. As shown in figure 3 the elicitor caused a marked inhibition at $0.01 \mathrm{mM}$. Figure $4 \mathrm{~A}$ shows that the root length was nearly $30 \%$ shorter and the number of emerged lateral roots (LR) decreased by $40 \%$ with the oligogalacturonide (figure 4B). Lateral root density was also calculated by dividing the number of lateral roots by the length of the primary root to normalize for the effects of $\mathrm{OGA}_{10}$ on primary root length (figure $4 \mathrm{C}$ ). This data indicates that the elicitor altered both primary and lateral roots with an inhibitory effect. This effect could not be eliminated by a stimulatory concentration of auxin ( $0.01 \mu \mathrm{M}$ NAA) as shown in figure 5 although root elongation was stimulated by the hormone. Auxin is known to promote root elongation and lateral root initiation (Graham et al., 2001) and there is a clear response of primary bean root to NAA. 


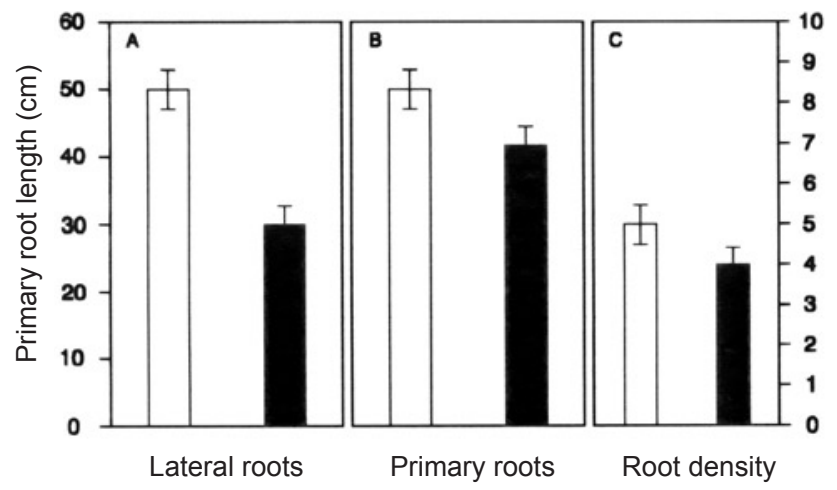

Figure 4. Root phenotype of bean seedlings incubated with $0.01 \mu \mathrm{M} \mathrm{OGA}_{10}$ for 3 days. Panel A shows the number of lateral roots (LR) per plant, length of the main root is in Panel $\mathrm{B}$ and root density (RD) in Panel C. Treated plants (closed bars); Control plants (open bars).

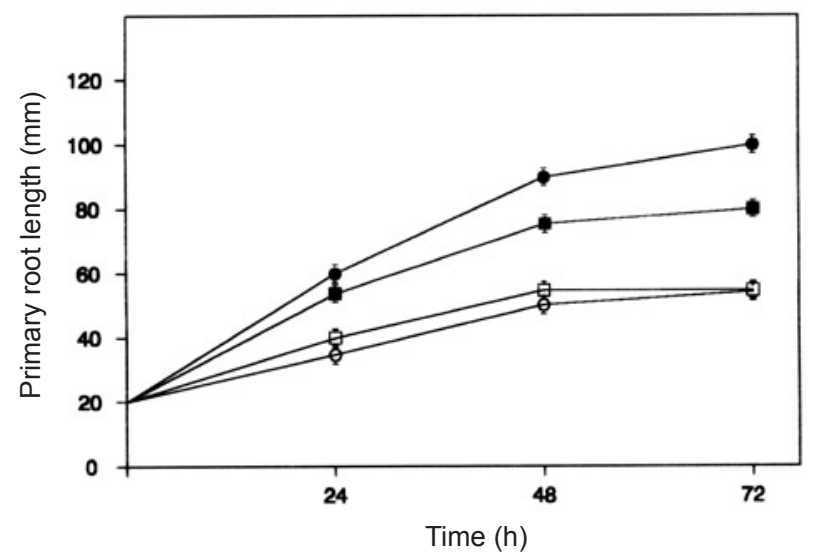

Figure 5. Kinetic analysis of auxin-stimulated roots. Seedlings were grown for 3 days in a nutrient solution containing 0.01 $\mu \operatorname{MNAA}(\bullet) ; 0.01 \mathrm{mM} \mathrm{OGA}_{10}(\bullet)$ or 0.01uM NAA plus 0.01 $\mathrm{mM} \mathrm{OGA}_{10}(\bigcirc)$; Control plants $(\square)$.

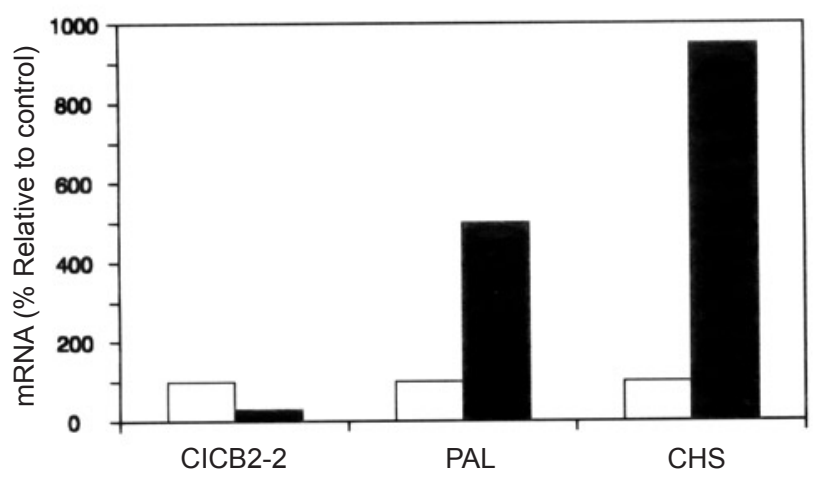

Figure 6. mRNA expression in P. vulgaris roots. After $48 \mathrm{~h}$ incubation with $0.01 \mathrm{mMOGA}_{10}$ levels of pal mRNA, chs mRNA and $C y c b 2-2$ mRNA (closed bars) were determined by Densitometric Analysis and plotted as relative to control values (open bars).
The role of galacturonides in plant development has been cast as that of an antagonist to auxin (Bellicampi et al., 1993) with the suggestion that transcriptional alteration of auxindependent genes occurs with galacturonides (Mauro et al., 2002). Since the effect on root growth was more evident at 48 and $72 \mathrm{~h}$ after treatment, mRNA levels of $C y c b 2-2$, a gene involved in cell division was tested at 48 and $72 \mathrm{~h}$. The mRNA corresponding to $C y c b 2-2$ was inhibited by $\mathrm{OGA}_{10} 48 \mathrm{~h}$ after treatment (figure 6) and remained so up to $72 \mathrm{~h}$. The defense response genes ( $\mathrm{pal}$ and $\mathrm{chs}$ ) remained highly elevated at $48 \mathrm{~h}$ after $\mathrm{OGA}_{10}$ treatment (figure 6) and returned to lower levels at $72 \mathrm{~h}$ (data not shown). The decreased expression of Cycb2-2 suggested that cell division was altered in the roots and indeed, addition of NAA did not revert the changes effected in the root architecture by the elicitor. It would seem that when the plant is directed to defend itself, the action of the auxin is momentarily ineffective.

\section{REFERENCES}

Bellicampi D, Salvi G, DeLorenzo G, Cervone F, Marfá V, Eberhard S, Darvill A, Albersheim P (1993) Oligogalacturonides inhibit the formation of roots in tobacco explants. Plant J. 4:207-213.

Cramer CL, Bell JN, Ryder TB, Bailey JA, Schuch W, Bolwell GP, Robbins MP, Dixon RA, Lamb CJ (1985) Coordinated synthesis of phytoalexin biosynthetic enzymes in biologically-stressed cells of bean (Phaseolus vulgaris L). EMBO J. 4:285-289.

Cano H, Zavala G, López-Romero E, Soriano E (1994) Oligosaccharides of plant and fungal origin elicit phaseollin accumulation with similar kinetics in bean (Phaseolus vulgaris L.) plants. Rev. Mex. Fitopatol. 12:162-173.

Capodicasa C, Vairo D, Zabotina O, McCartney L, Caprari C, Mattei B, Manfredini C, Aracri B, Benen J, Knox JP, De Lorenzo G, Cervone F (2004) Targeted modification of homogalacturonan by transgenic expression of a fungal polygalacturonase alters plant growth. Plant Physiol. 135: 1294-1304.

De Lorenzo G, D'Ovidio R, Cervone F (2001) The role of polygalacturonase-inhibiting proteins (PGIPs) in defense against pathogenic fungi. Annu. Rev. Phytopathol. 39:313335.

Dixon RA, Jennings AC, Davies LA, Gerrish G, Murthy DL (1989). Elicitor-active components from french bean hypocotyls. Physiol. Mol. Plant Pathol. 34:99-115.

Graham N, Inze D, Sandberg G, Casero PJ. (2001). Auxin transport promotes Arabidopsis lateral root initiation. Plant Cell 13:843-852.

Maniatis T, Fritsch EF, Sambrook J (1982) Molecular cloning: A Laboratory Manual. $2^{\text {nd }}$ edn. Cold Spring Harbor Laboratory Press, New York. 
Maher EA, Bate NJ, Ni W, Elkind Y, Dixon RA, Lamb CJ (1994) Increased disease susceptibility with suppressed levels of preformed phenylpropanoid products. Proc. Natl. Acad. Sci. USA 91:7802-7806.

Mauro M L, De Lorenzo G, Constantino P, Bellicampi D (2002) Oligogalacturonides inhibit the induction of late but not early auxin-responsive genes in tobacco. Planta 215:494-501.

Pawlowski K, Kunze R, de Vries S, Bisseling T (1994). Isolation of total, poly(A) and polysomal RNA from plant tissues, In: Gelvin SB and Schilpeerot RA (eds), Plant Molecular Biology Manual, pp. D5/1-13. Kluwer Academic Publishers, Dordrecht.

Richard S, Lapointe G, Rutledge RG, Séguin A (2000) Induction of Chalcone Synthase expression in white spruce by wounding and jasmonate. Plant Cell Physiol. 41:982-987.

Ridley BL, O'Neill MA, Mohnen D (2001) Pectins: structure, biosynthesis and oligogalacturonide-related signaling. Phytochemistry 57:929-967.
Shevell DE, Kunkel T, Chua NH (2000) Cell wall alterations in the arabidopsis emb30 mutant. Plant Cell 12:2047-2060.

Soriano E, Garcia E (1993) Microassay to measure phytoalexin responses in protoplasts of bean leaves. Phytochem. Anal. 4: $82-85$

Spiro MD, Kates KA, Koller AL, O'Neill MA, Albersheim P, Darvill A (1993) Purification and characterization of biologically active 1,4-linked $\alpha$-D-oligogalacturonides after partial digestion of polygalacturonic acid with endopolygalacturonase. Carbohyd. Res. 247:9-20.

Spiro MD, Bowers JF, Cosgrove DJ (2002) A comparison of oligogalacturonide- and auxin-induced extracellular alkalinization and growth responses in roots of intact cucumber seedlings. Plant Physiol. 130:895-903.

Theodorou MK, Scanlon CM, Smith JM (1982) Infection and phytoalexin accumulation in french bean leaves infected with spores of Colletotrichum lindemuthianum. Phytopathology 103:189-197. 